\title{
UNDERGROUND PO ŚLĄSKU
}

\section{UNDERGROUND MUSIC SCENE IN SILESIA}

\begin{abstract}
Upper Silesia is usually associated with the historical land situated in southern Poland with highly developed industry, mainly mines and steelworks. The inhabitants of Upper Silesia are perceived as conservatist. In spite of that, it is Upper Silesia, precisely Gliwice, where the most vigorous underground music scene in communist Poland was created at the beginning of the 1980s. The Gliwice Alternative Scene was focused around student clubs in Gliwice with "Gwarek" as the representative one. In this article we will show the artistic legacy of chosen musical bands from GAS such as Smierc Kliniczna, R.A.P., Absurd, Processs, Brzytwa Ojca. In particular we will analyze the lyrics and quote interviews with the musicians from the before mentioned bands. We will therefore demonstrate that the Gliwice Alternative Scene was not only an alternative to the blues scene, which was very popular in Upper Silesia, but also through the fusion of punk, reggae and new wave as well as unconventional, radical lyrics, it stood out among other bands which created the Polish underground musical scene of the 1980s. In terms of its social impact, it was a "niche within a niche". Finally, it is worth noting that the Gliwice Alternative Scene was beyond censorship and the dominant communist discourse.
\end{abstract}

Key words: Gliwice Alternative Scene; punk rock; reggae; new wave DIY

Streszczenie

Gliwicka Alternatywna Scena (GAS) była jednym z najprężniej rozwijających się środowisk alternatywnego rocka w Polsce
MIROSŁAW PĘCZAK Uniwersytet Warszawski, Warszawa E-mail:m.peczak@polityka.pl

PIOTR ZAŃKO Uniwersytet Warszawski, Warszawa E-mail: piotr.zanko@gmail.com

CITATION: Pęczak, M., \& Zańko, P. (2018). Underground po śląsku. Sprawy Narodowościowe. Seria nowa, 2018(50). https://doi.org/10.11649/sn.1739

This work was supported by the authors' own resources. No competing interests have been declared. Both authors participated in elaborating research ideas and writing the manuscript.

This is an Open Access article distributed under the terms of the Creative Commons Attribution 3.0 PL License (creativecommons.org/licenses/by/3.0/pl/), which permits redistribution, commercial and non-commercial, provided that the article is properly cited. (C) The Author(s) 2018.

Publisher: Institute of Slavic Studies, Polish Academy of Sciences 
lat 80. Organizowała się od początku tamtej dekady w gliwickich klubach studenckich, z których najbardziej emblematycznym miejscem okazał się "Gwarek". Najważniejszymi zespołami GAS były: Śmierć Kliniczna, R.A.P., Absurd, Processs, Brzytwa Ojca. W tekście skupiamy się w szczególności na analizie tekstów piosenek wymienionych zespołów oraz treści wywiadów narracyjnych, prasowych, radiowych przeprowadzonych z muzykami współtworzącymi GAS. Wynika z nich, że opisywane przez nas zjawisko dobrze oddawało ducha całej polskiej alternatywy ostatniej dekady PRL, jak i pozostawało fenomenem specyficznym w skali regionalnej.

Stowa kI u c zo we: Gliwicka Alternatywna Scena (GAS); punk rock; reggae; nowa fala; DIY

N azwa Gliwicka Alternatywna Scena (GAS) ${ }^{1}$ funkcjonuje w obiegu społecznym od lat i stosuje się ją do opisania twórczości zespołów alternatywnego rocka działających głównie na terenie Gliwic w latach 1982-1990. Choć jak twierdzi gitarzysta Dariusz Dusza, jest ona stosowana nieco na wyrost. W tym sensie, że zespoły identyfikowane z GAS, takie jak Śmierć Kliniczna, ale też R.A.P., Brzytwa Ojca, Absurd, Processs nie podejmowały pod tą nazwą żadnych wspólnych działań, jak czyniły to na przykład zespoły tworzące w latach 80. Gdańską (Trójmiejską) Scenę Alternatywną (Dusza, 2016, ss. 124-125).

Gliwicka Alternatywna Scena zdążyła obrosnąć w kręgach polskiej kontrkultury legendą sceny muzycznej wymykającej się klasyfikacjom. Sceny będącej swoistym miksem punk rocka, post punka, nowej fali i reggae. Pomimo to ten fenomen polskiego undergroundu lat 80. - poza tekstami Jerzego Wertensteina-Żuławskiego (1993), Mirosława Pęczaka (Pęczak 1992) oraz Marty Marciniak (2015) - nie był przedmiotem zbyt wielu analiz naukowych

W artykule przybliżamy historię GAS. Analizujemy teksty piosenek zespołów z tą sceną związanych, aby pokazać, w jaki sposób opowiadały one o rzeczywistości społeczno-politycznej (o świecie relacji międzyludzkich, sytuacji młodzieży etc.) ostatniej dekady PRL. Okresu na wskroś burzliwego, obejmującego narodziny Solidarności i wprowadzenie stanu wojennego, który pociągnął za sobą ogromne konsekwencje społeczne: emigrację około miliona Polaków, zapaść gospodarczą, zniszczenie kapitału zaufania społecznego i wycofanie się obywateli do sfery prywatnej. Treści piosenek GAS traktujemy jako formę komunikacji wewnątrzpokoleniowej odzwierciedlającej stany świadomości młodzieży żyjącej w latach 80. (Wertenstein-Żuławski, 1993, s. 65).

Istotnym źródłem informacji o GAS - oprócz dostępnych dokumentów (artykułów prasowych, informacji zawartych we wkładkach płyt kompaktowych, autobiografii, wywiadów prasowych i radiowych) - był wywiad narracyjny z Dariuszem Duszą, gitarzystą zespołów Śmierć Kliniczna i Absurd, przeprowadzony w czerwcu 2015 roku przez współautora artykułu. Wywiad ten prawie w całości wykroczył poza historie jednostkową rozmówcy i przyjął formę historii mówionej (oral history). Dariusz Dusza podczas rozmowy często przywoływał historię osób zaangażowanych w działalność GAS, a także tworzących undergroundową scenę muzyczną w Polsce lat 80. (Bornat, 2004, ss. 34-47, cyt. za: Kvale, 2010, s. 129).

W opowieści o gliwickim undergroundzie skupiliśmy się na najbardziej rozpoznawalnych zespołach tworzących GAS: Śmierć Kliniczna, R.A.P., Processs, Absurd, Brzytwa Ojca. Wystąpity one na Festiwalu Muzyków Rockowych w Jarocinie - największym w la-

\section{.......}

Prawdopodobnie nazwa Gliwicka Alternatywna Scena została ukuta przez "Pastora”, wokalistę punkowego zespołu Brzytwa Ojca. Informacja uzyskana od Dariusza Duszy podczas wywiadu narracyjnego (D. Dusza, wywiad narracyjny, czerwiec 2015). 
tach 80. festiwalu muzyki rockowej w Polsce i prawdopodobnie także w Europie Wschodniej. Niektóre zaistniały również w dyskursie medialnym. W 1983 roku powstał nakręcony przez Pawła Karpińskiego film dokumentalny pt. Śmierć Kliniczna. Rok później ten sam reżyser uwiecznił występ zespołu w filmie fabularnym To tylko rock. Z kolei fragmenty koncertów zespołów R.A.P. i Processs zostały udokumentowane w 1985 roku przez Andrzeja Kostenkę w filmie Moja krew, twoja krew (My Blood, Your Blood) zrealizowanym na zamówienie telewizji BBC.

Należy zacząć od podkreślenia, że Górny Śląsk ma własną, wyraźnie inną niż na przykład małopolska, mazowiecka czy wielkopolska, tradycję muzyczną. Historycznie rzecz biorąc kształtowała się ona podobnie, jak działo się to $w$ tych europejskich regionach, gdzie już pod koniec XVIII wieku zaczęły się forsowne procesy uprzemysłowienia, których efektem było między innymi powstanie kultury robotniczej. Muzyka w całokształcie tej kultury zajmowała miejsce ważne, bo była z jednej strony wehikułem tradycji i pamięci społecznej, z drugiej zaś przejawem aktualnej ekspresji środowiskowej, lokalnej i regionalnej. Łączyła zatem rustykalną przeszłość z miejską teraźniejszością. Odrębności poszczególnych folklorów w dużym stopniu stanowiły residuum wiejskiej przeszłości, ale specyfika osiedli budowanych wokół kopalń, hut i fabryk była podobna w północnej Francji, w Nadrenii, czy w okolicach Katowic. Podobne były też specyficzne dla tych regionów praktyki kulturowe, takie choćby jak domowe muzykowanie, zakładanie chórów, czy granie w organizowanych przez robotników orkiestrach. Oczywiście, dawny Śląsk muzyczny kojarzy się w pierwszym rzędzie z orkiestrami dętymi.

Tradycje orkiestr dętych sięgają na Śląsku XIX wieku. W czasie wolnym górnicy zbierali się, by muzykować dla przyjemności, a na specjalne okazje, zwłaszcza na Barbórkę, przywdziewali mundury, by grać podczas marszu do kościoła, gdzie odbywało się uroczyste nabożeństwo. Inni tworzyli kapele weselne, które równie chętnie przygrywały na zabawach ludowych i festynach. Szczególny rozkwit orkiestr dętych na Górnym Śląsku zaczyna się w pierwszej dekadzie XX wieku. Zakładały je środowiska Ochotniczych Straży Pożarnych, kolejarze, no i oczywiście górnicy (Szwed, 2010). Typowy przypadek mógtby dotyczyć muzycznej historii Mysłowic. Pierwszą zorganizowaną orkiestrę dętą górników z kopalni w Mysłowicach, czyli w Myslowitz, założył w 1920 roku Antoni Dawid, znawca i admirator brzmienia tub, helikonów, waltorni, trąbek, puzonów, sakshornów, kornetów i suzafonów. Dyrektor kopalni Otto Fritsch sprowadził wtedy z Niemiec galowe stroje i komplet wysokiej klasy instrumentów. Całe Myslowitz było dumne ze swojej orkiestry (Winnicka, 2000, ss. 100-105).

Wpływom niemieckim, a po części także czeskim, Górny Śląsk zawdzięcza bogate tradycje muzykowania domowego. Podobnie rzecz się ma z popularnością śpiewania w amatorskich chórach. W początkach PRL muzyczny Śląsk zainteresował badaczy-muzykologów, a także animatorów kultury muzycznej. W 1953 roku Stanisław Hadyna za†ożył Zespół Pieśni i Tańca „Śląsk". Uładzona, pozbawiona pierwotnej surowości śląska muzyka ludowa miała być wizytówką regionu, a zarazem stanowiła efekt dyrektywy państwowej, czyli partyjnej, polityki kulturalnej, realizowanej zgodnie ze stynnym zaleceniem Stalina, wedle którego postępowa sztuka jest „socjalistyczna w treści i narodowa (ludowa) w formie”. Dlatego zespół "Śląsk”, obok takich pieśni jak Karolinka czy Szła dzieweczka do laseczka, miał w repertuarze wiele utworów nowo powstałych, sławiących sukcesy załóg kopalnianych i rozkwit Ludowej Ojczyzny. Jedna z takich nowych pieśni uwznioślających trud górniczy rozbrzmiewała w latach 50. i 60. w czołówce katowickiego ośrodka TVP. 
Śląsk muzyczny to także, a dla szerokiej publiczności przede wszystkim, powojenna muzyka rozrywkowa, której emblematycznymi postaciami byli między innymi Maria Koterbska, Janusz Gniatkowski czy Zygmunt Wichary. Ten ostatni w 1954 roku założył jeden z pierwszych zespołów jazzowych w powojennej Polsce. Po 1956 roku zespoły i soliści ze Śląska mieli istotny udział w tworzeniu polskiego mainstreamu muzyki rozrywkowej. W latach 70. w Akademii Muzycznej im. Karola Szymanowskiego w Katowicach otwarto instytut jazzu, a w efekcie uruchomiono kierunek jazzu i muzyki rozrywkowej, którego pierwszymi absolwentami byli Krystyna Prońko, Lora Szafran czy Stanisław Sojka, a potem Mietek Szcześniak. "Szkoła katowicka” wywarła wyraziste piętno na ofercie muzyczno-rozrywkowej polskich mediów i fonografii, choć przede wszystkim na tej jej części, która stanowiła kontrapunkt dla nowych i modnych nurtów muzycznych, zwłaszcza dla rodzimego rocka ostatniej dekady PRL. „Katowice” kontra „Jarocin”... Ten, kto lubił śpiew Krystyny Prońko, nie miał zwyczaju bywać na koncertach Dezertera. Tak to się prezentowało w praktyce.

$W$ latach 80. Śląsk był przez fanów rocka traktowany jako matecznik bluesa i heavy metalu. W 1981 roku znany z wcześniejszych występów między innymi w zespołach Breakout i SBB Irek Dudek zorganizował pierwszą edycję Rawy Blues - jak się potem okazało, najważniejszego festiwalu bluesowego w Polsce. Od tej pory co roku zjeżdżali do Katowic wybitni bluesmani z całego świata. Ze Śląska wywodzą się też krajowe gwiazdy tej muzyki - zespoły SBB, Dżem, Krzak, a regionalną wersję bluesa z tekstami w gwarze śląskiej rozpowszechniał Jan „Kyks” Skrzek, brat lidera i założyciela SBB Józefa Skrzeka.

Z kolei tragiczna postać Ryszarda Riedla skojarzyła muzyczny Śląsk z legendą posthipisowską. Niedługo później Śląsk zasłynął jako centrum heavy metalu. Metal rozwinął się tu jeszcze przed pierwszą odsłoną organizowanego od 1986 roku festiwalu Metalmania, ale przede wszystkim dzięki mrocznemu i agresywnemu w brzmieniu zespołowi Kat (Kat to nie tylko kat, ale i początek nazwy "Katowice”).

Gliwicka Alternatywna Scena niemal od początku ostatniej dekady PRL była wpisana w ten krajobraz, ale również stanowiła część szerszego zjawiska określanego jako polski boom rockowy. U schyłku lat 70. zaczęły się pojawiać zespoły, które zerwały z wcześniejszą praktyką ulegania restrykcyjnym nakazom i nawykom polityki kulturalnej polegającą na unikaniu mocnego brzmienia i - w ogóle - zbyt ostentacyjnego manifestowania estetycznej, a przede wszystkim ideologicznej niezależności. Z drugiej strony partyjni sternicy kultury i rozrywki przekonali się, że nie da się tak skutecznie jak w przeszłości kontrolować i kanalizować zainteresowania muzyczne młodych ludzi. Nie blokowano zatem takich inicjatyw jak animowany przez muzycznych menedżerów (Waltera Chełstowskiego, Jacka Sylwina, Wojciecha Korzeniowskiego i Marcina Jacobsona) projekt Muzyka Młodej Generacji polegający na promowaniu i wspieraniu logistyczno-organizacyjnym młodych zespołów rockowych. Skorzystały z tego takie zespoły, jak Exodus, Krzak, Kombi, Mech, Kasa Chorych. Wkrótce dały o sobie znać kolejne formacje, które od razu zyskały olbrzymią popularność: Maanam, Perfect, a niedługo potem TSA, Turbo, Oddział Zamknięty, Republika i Lady Pank.

Równocześnie z „maistreamowym” rockiem eksplodował polski punk rock. Historycznie pierwsi jego przedstawiciele to warszawskie Tilt, Brygada Kryzys, Deuter, SS 20 (późniejszy Dezerter), TZN Xenna, gdański Deadlock i KSU z Ustrzyk Dolnych, założone najwcześniej, bo w 1977 roku. Wszystkie zaliczamy do tak zwanej pierwszej fali polskiego punka, do której nota bene należy także gliwicka Śmierć Kliniczna (Pęczak, 2013, s. 109). W latach 1983-1984 formuje się „druga fala” z takimi zespołami, jak Siekiera, Armia, Moskwa, 1984 czy założony przez ex-lidera Śmierci Klinicznej Darka Duszę Absurd współtwo- 
rzący GAS. Różnica między oboma tymi „wysypami” punkowych kapel polega głównie na tym, że te wcześniejsze, zwłaszcza Tilt i Deadlock, do pewnego stopnia także Śmierć Kliniczna, starały się inspirować różnymi wariantami muzyki punkowej, a niekiedy wchodziły w fuzje z innymi stylami, jak reggae, czy nawet (jak Śmierć Kliniczna) jazz rock. Natomiast druga fala to zdecydowanie mocniejsze brzmienie, bliskie ortodoksyjnemu punkowi brytyjskiemu (GBH, UK Subs), czy nawet początkom amerykańskiego hard core'u. Na całym tym tle GAS, czy to w wydaniu punkowym, czy reggae'owym (vide: R.A.P.), wydaje się najbliższa inspiracjom brytyjskim.

Wybór wzorca brytyjskiego przez śląskich adeptów punk rocka mógł mieć szczególne podłoże. Otóż rock brytyjski, od zespołów mody skifflowej z lat 50. począwszy, poprzez glam, aż do punk rocka i new romantic, rozwijał się przede wszystkim w środowiskach młodzieży robotniczej i był przejawem kryzysu i rozpadu tradycyjnego modelu angielskiej kultury robotniczej (Hoggart, 1976). Muzyka ta jak nigdzie na świecie była silnie związana z kolejnymi falami subkultur młodzieżowych, których rodowód brał się właśnie z konfliktu pokoleń wewnątrz klasy robotniczej. Trudno mówić, że na Śląsku wszystko przebiegato dokładnie tak jak w Anglii, ale Śląsk, a zwłaszcza aglomeracja górnośląska, to jedno z niewielu miejsc w Polsce, które, jak zaznaczyliśmy wcześniej, może się poszczycić długimi i bogatymi tradycjami kultury robotniczej. Tutaj również - w Katowicach, Gliwicach, Mysłowicach, jak w Manchesterze, Liverpoolu czy Londynie - młodzi podążali za modą i chcieli się samodzielnie określić. Pomagała im w tym muzyka, skrajnie inna niż ta, która dawniej rozbrzmiewała na organizowanych przez zakłady pracy potańcówkach. Angielski rock, będący ekspresją młodzieżowych subkultur odrzucających zastane kody i reguły, chciał być na swój sposób wyrafinowany, jak na swój sposób wyrafinowane były surduty teddy boys czy marynarki i wąskie krawaty modsów. Dokładnie to samo dotyczy granego na Śląsku w latach 80. punka, nowej fali czy reggae, które odróżniały się zarówno od "starych tradycji", jak i współczesnych sobie konkurencyjnych gatunków muzycznych, łącznie ze śląskim bluesem czy metalem.

\section{DZIECI ŚLĄSKICH BLOKÓW I "OBSYFIALYCH” KAMIENIC}

Bardzo duży wpływ na rozwój Gliwickiej Alternatywnej Sceny miały kluby studenckie Politechniki Śląskiej: „Gwarek”, "Spirala” „Program” i „Kropka” oraz Międzyzakładowy Dom Kultury w Łabędach², w którym próby miał zespół Processs i w którym odbywał się również przegląd młodych zespołów rockowych "Postrzyżyny".

Z narracji Dariusza Duszy (2015) wynika jasno, że istniał ścisły związek między gliwicką kulturą alternatywną a kulturą studencką. W tym sensie, że ta pierwsza właściwie zawdzięcza swoje istnienie i rozwój śląskim żakom. Na szczególną uwagę zasługuje tutaj działalność klubu „Gwarek”, w piwnicy którego odbywały się między innymi próby Śmierci Klinicznej i Absurdu. Notabene, piwnica jako miejsce prób ma tutaj znaczenie symboliczne. Gitarzysta Śmierci Klinicznej przeciwstawia ją garażowi jako przestrzeni adaptowanej do prób przez niektóre zespoły rockowe ze Stanów Zjednoczonych: „Śmierć Kliniczna nigdy nie była zespołem garażowym. Garażowe to mogły być kapele amerykańskich burżujów, których rodzice mieli jednorodzinne domki. My, dzieci bloku i obsyfiałej kamienicy graliśmy w piwnicy" (Dusza, 2016, s. 121). Dodajmy, za gitarzystą Absurdu, że próby od-

2 Łabędy to jedno z gliwickich osiedli. 
bywały się w warunkach niekiedy odbiegających od standardów sanitarnych: "Cały czas pod nogami czuliśmy coś miękkiego, trochę też śmierdziało. Gdy w końcu Lumpaj, wokalista Absurdu, wkręcił żarówkę, zobaczyliśmy dziesiątki martwych szczurów, które zalegały w całym pokoju. Prowadzono akcję deratyzacyjną i one przychodziły tam zdychać" (Dusza, 2016, s. 121).

Pisząc o Klubie "Gwarek”, należy wspomnieć o Wojciechu Kurdzielu, działaczu studenckim, pierwszym menedżerze Śmierci Klinicznej, autorze kilku ważnych jej tekstów, między innymi utworu „W potylicę", o którym mowa będzie później. W latach 1982-1984 Kurdziel kierował również „Gwarkiem”, i jak wspomina Dariusz Dusza, gliwicki klub stał się wówczas centrum kultury alternatywnej nie tylko na Śląsku:

Bywały tygodnie, w których odbywały się [w "Gwarku - przyp. aut.] aż trzy koncerty (...) Jeśli chodzi o ilość i jakość koncertów kasowat wszystkie inne polskie kluby (...) W latach 82-86 grali u nas wszyscy. Zarówno zachodnie punkowe zespoły takie jak Youth Brigade, Totenhosen, czy D.O.A. jak i cała czołówka polskiej sceny [undergroundowej - przyp. aut.] (Dusza, 2016, ss. 89-124).

„Gwarek" oprócz roli kulturotwórczej ze względu na swoje umocowanie instytucjonalne i eksterytorialny charakter niejednokrotnie chronił muzyków przed represjami ze strony ówczesnej władzy. Jak wspomina gitarzysta Śmierci Klinicznej: „Kluby ratowały nam też dupę, dając dokument w stylu":

„Zaświadcza się, że obywatel Dariusz Dusza legitymujący się dowodem numer ten i ten jest członkiem zespołu Śmierć Kliniczna działającym przy Klubie Gwarek" (...) Jak nie byłeś już na studiach, nie pracowałaś, czy nawet byłeś na urlopie to się władza tobą interesowała i polowała na "niebieskich ptaków”. Mój rekord to osiemnaście zatrzymań przez milicję na trasie półtora kilometra, czyli dystansie od mojego domu do „Gwarka” (Dusza, 2015).

W PRL każda osoba nieucząca się, niepracująca, była dla władzy potencjalnie podejrzana. Nie wspominając o tym, że polska scena undergroundowa, pierwotnie przez władze ignorowana, stała się po delegalizacji Solidarności przedmiotem zainteresowania Służby Bezpieczeństwa, czego przykładem są działania operacyjne „bezpieki” w latach 19831989 w Jarocinie podczas odbywającego się tam największego w Polsce festiwalu muzyki rockowej (Lesiakowski, Perzyna, \& Toborek, 2004). Nie oznacza to jednak, że festiwal jarociński i promowana tam muzyka miały wyłącznie antykomunistyczny - w politycznym tego słowa znaczeniu - charakter. Był raczej kontestacją świata dorosłych, co obrazuje chociażby pierwotna wersja pierwszej zwrotki piosenki Dezertera pt. „Poroniona generacja”: „Żadnej satysfakcji, za dużo frustracji. Oto obraz mojej generacji. Żadnego celu, żadnej przyszłości. Ani w partii, ani w Solidarności" (Grabowski, 2010, s. 216). Mitologizacji Jarocina i w ogóle oficjalnego nurtu polskiego rocka lat 80. przeciwstawia się Dariusz Dusza:

Właśnie od pewnego czasu widzę wysyp różnych muzyków, rzekomo represjonowanych przez system. Czytam wywiady, w których cytowane są teksty piosenek z tamtych lat. Piosenek, które po tysiąc razy były emitowane w telewizji. Utworów, które rozbrzmiewały od Opola po Kołobrzeg. I dopiero teraz dowiedziałem się o czym są te piosenki! Teraz poznaję ich drugie dno, teraz bielmo spadło z oczu moich. Te wszystkie hity lat osiemdziesiątych to były kryptorewolucyjne protest songi! Dzięki nim runęła komuna. Gdyby nie kliku bohaterów (nie bójmy się nazywać rzeczy po imieniu) z głównego nurtu, nadal tkwilibyśmy w komunie. Ba, może nawet w feudalizmie. Rockmani wyklęci, w okopach orbisowskich hoteli. Zamiast z butelek z benzyną dzielnie dzierżyliście butelki z wódką. Na barykadach list przebojów niszczyliście komunę (Dusza, 2016, s. 77). 
Wypowiedź Duszy rezonuje z refleksjami innych muzyków tworzących w latach 80. undergroundową scenę muzyczną. Cytowany już Robert Brylewski konstatuje, że muzycy tworzący oficjalną scenę rockową byli w gruncie rzeczy profesjonalnymi pracownikami estrady, a zespoły w których grali - zespołami stadionowymi, idealnie trafiającymi w gusta polskiego słuchacza (Lizut, 2003, s. 58). Faktycznie, takie zespoły jak Perfect, Kombi, Manaam, Lady Pank, Republika, Lombard (niektóre z nich wystąpiły także na festiwalu jarocińskim) w przeciwieństwie do większości zespołów punk rockowych, mogły swobodnie nagrywać płyty, koncertować, a ich piosenki były bez większych problemów prezentowane $w$ radiu i w telewizji. Pomimo to w dyskursie medialnym coraz częściej można zetknąć się z opiniami sugerującymi jakoby zespoły z oficjalnego nurtu „walczyły z komuną". Dobrym przykładem mitologizacji oficjalnej sceny rockowej w Polsce jest zrealizowany w 2010 roku przez Leszka Gnoińskiego i Wojciecha Słotę film dokumentalny Beats of Freedom - Zew wolności. Po obejrzeniu filmu widz pozostaje z refleksją, że polski rock lat 80. nie tylko walczył z systemem komunistycznym, ale wręcz w znaczącym stopniu przyczynit się do jego obalenia. A jego demontażu dokonały przede wszystkim zespoły z głównego nurtu, z zespołem Perfect na czele. W dokumencie Gnoińskiego i Słoty nie ma natomiast mowy o tym, że na przyklad zespół Zbigniewa Hołdysa był przez muzyczny underground (w filmie zmarginalizowany) traktowany jako w istocie rzeczy zespół mainstreamowy. Pewnie nie bez powodu punkowy Dezerter wykonał na festiwalu jarocińskim w 1982 roku (wtedy jeszcze pod nazwą SS 20) utwór "Nie płacz Zbyszek”, wprost kontestujący twórczość Perfectu:

Wszystko jest dopracowane. Bardzo dobrze dopasowane. Wszystko jak w zegarku gra. Zespół Perfect ogniem sra. Czym nowym nas zaskoczą? Czym nas nowym zauroczą? Głos krytyków się wpierdala, że Perfect to nowa fala. Ich muzyka jest wspaniała. Ich muzyka doskonała. Tego pragnie mój organizm. To jest lepsze niż onanizm; Banda zgredów i szpanerów. Do estrady się dorwała. To jest młoda generacja. Tylko trochę wyłysiała ${ }^{3}$.

Dyskusja o mitologizacji polskiego rocka lat 80. zasługuje na odrębne opracowanie, jednak wróćmy do GAS. Przyjrzyjmy się bliżej historiom poszczególnych zespołów.

\section{"NASZE REALIA TO ANOMALIA"}

Jednym z ważniejszych - o ile nie najważniejszym zespołem GAS - była Śmierć Kliniczna. Zespół powstał w 1981 roku w Gliwicach, założony przez Dariusza Duszę (gitara), Jerzego Mercika (śpiew), Wojciecha Jaczyczko (gitara basowa) i Marka Czapelskiego (perkusja). Dwa lata później Jerzego Mercika zastąpił Jacek Szafir. Z zespołem współpracowali: Antoni Gralak (trąbka), Mateusz Pospieszalski (saksofon) i Piotr Malak (saksofon), muzycy jazzowi i rockowi, znani chociażby z występów z zespołem Tie Break, VOO VOO czy T.Love. Oto jak początki działalności „Śmierci Klinicznej” wspomina Dariusz Dusza:

Jeszcze przed epoką Śmierci Klinicznej grałem w różnych efemerycznych formacjach. Graliśmy standardy bluesowe, rock'n'rollowe, trochę numerów Creamów, Hendrixa. Cały czas szukałem możliwości zrobienia czegoś swojego oryginalnego. A z muzyką punkową zetknąłem się gdzieś w 1980 roku. Podobała mi się jej świeżość i siła, szczególnie na tle innej żałosnej muzyczki, jaką grywano w tamtych czasach (Śmierć Kliniczna, 2001).

3 Utworu SS 20 można posłuchać na: https://www.youtube.com/watch?v=s2z4Ob_7tiA (SS 20, b.d.). 
Początkowo grupa działała pod nazwą "Uśmiech Modliszki” i dała się poznać najpierw gliwickiej publiczności, grając swój pierwszy koncert w maju 1982 roku przed gliwickim klubem „Gwarek”. Szerszej publiczności zaprezentowała się trzy miesiące później - już jako Śmierć Kliniczna - podczas III Ogólnopolskiego Festiwalu Muzyki Młodej Generacji w Jarocinie. Koncert ten zapoczątkował serię występów zespołu w całej Polsce, na najważniejszych wówczas festiwalach muzycznych takich, jak: Grand Festival Róbrege, Festiwal Artystyczny Młodzieży Akademickiej (FAMA), Camping Muzyczny w Brodnicy, Rockowisko w Łodzi, Rock w Opolu, Rock Arena w Poznaniu (Dusza, 2015).

Zespół eksperymentował z brzmieniem. Włączenie do podstawowego składu instrumentów kojarzonych z muzyką jazzową (trąbka, saksofon) na stałe umiejscowiło Śmierć Kliniczną w grupie najbardziej awangardowych kapel punk rockowych w Polsce lat $80 . \mathrm{Na}$ czym polegał fenomen Śmierci Klinicznej? Jak zwraca uwagę Dariusz Dusza:

Siła tego zespołu tkwiła w ciągłym, twórczym konflikcie. Żadnych blokad ani ograniczeń. Taka muzyczna anarchia. Spotykaliśmy się często, każdy miał trochę inne pomysły i fascynacje (...) Nie mieliśmy żadnych gotowych wzorców, czy szablonów, wręcz nie chcieliśmy grać i brzmieć jak inni. Nie tworzyliśmy również z premedytacją, czy pod publiczkę. Stąd tak różnorodny stylistycznie repertuar. Stąd problemy odbiorców i krytyków: punk, new wave czy reggae? (Śmierć Kliniczna, 2001).

Trudno jednoznacznie określić styl Śmierci Klinicznej. Na przykład w utworze „Psychopata" usłyszeć można zarówno elementy muzyki punkowej, jak i jazzowo rockowej. Piosenka, która początkowo miała się ukazać na drugim singlu zespołu "Jestem ziarnkiem piasku", wydanym w 1984 roku przez Tonpress, ze względu na swą antysystemową wymowę została odrzucona przez cenzurę. Z tekstu wyłania się obraz człowieka żyjącego w poczuciu permanentnego lęku i strachu. Jak zauważył celnie Sebastian Chosiński (2012), utwór ten „nie był tylko zapisem paranoi podmiotu lirycznego, ale diagnozą peerelowskiej rzeczywistości epoki stanu wojennego - ze wszechobecną podejrzliwością i szpiclowaniem”. W piosence „Psychopata” Śmierć Kliniczna śpiewa:

Samochody po ulicach rozbestwione gonią mnie. Cegła z dachu spaść mi może, między ludźmi boję się. Kiedy jestem sam w mieszkaniu telewizor straszy mnie. Zamki w drzwiach mam takie słabe, ktoś mnie chyba zabić chce (...) Wszystko mnie napawa lękiem, ciągle w febrze cały drżę. Życie dla mnie ciągłą męką, pragnę uciec, schować się. Mówią jesteś psychopata, dom bez klamek dać mi chcą. Ale przecież nienormalni właśnie oni są. Jestem sam, pozabijam was! (Śmierć Kliniczna, 2001).

W podobnej punkowo-jazzowej poetyce utrzymany jest utwór "ASP" nagrany przez zespół w 1983 roku podczas sesji do pierwszego singla "Nienormalny świat”. Ostatecznie piosenka ujrzała światło dzienne rok później i została wydana na drugim singlu zespołu, zamiast, zdjętego przez cenzurę, utworu „Psychopata”. Tytuł "ASP” - jak wyjaśnia Dusza - jest skrótem od pierwszych liter kolejnych zwrotek tekstu: „Automatyczna prokreacja, „Syntetyczne usta i uśmiechy, „Programowane impulsy nerwowe” [podkreślenie aut.] (Dusza, 2015). Z tekstu wyłania się obraz świata zdominowanego przez inżynierię społeczną, automatyzację i standaryzację. Refren wyraża pragnienie wyzwolenia się jednostki z owego huxley'owskiego koszmaru: „Ja chciałbym wyjść poza schemat. Zrobić coś niezgodnie z planem. Nie mogę, gdy mi przeszkadzają ludzie maszyny zdalnie sterowane!" (Śmierć Kliniczna, 1984).

Z kolei w utworze "W potylicę”, do którego słowa napisał Wojciech Kurdziel, Śmierć Kliniczna zaskakuje odbiorców reaggową stylistyką. Tekst piosenki jest nie tyle wiwisek- 
cją represyjnego systemu politycznego, ile wyrazem rozczarowania młodych światem dorostych:

W domu, w szkole, na ulicy wszędzie żyją jadowici (...) Mają grzechy i zasady, oszczędności, raty, wkłady. Mają szpiegów swego wroga. Mają wiare w swego Boga. Śpią w kolejkach, dyskutują. Stroją pozy, kopulują. Żyć normalnie dla nich bzdura, pierwotniaki w ludzkich skórach (Śmierć Kliniczna, 2001)

W repertuarze Śmierci Klinicznej znajdziemy również utwory kontestujące instytucje państwowe. W piosence "Nasza edukacja”, która ukazała się na pierwszym singlu zespołu, krytyce poddany został polski system edukacyjny. W utworze będącym swoistym miksem ska i rock'n'rolla szkołę ukazano jako instytucję, w której królują konformizm i mechaniczne przyswajanie utartej wiedzy przez uczniów:

Czy też chcemy czy nie chcemy. Na pamięć wszystko umiemy. Pan profesor tak to lubi. Edukacja - Kopulacja. Nie myślimy nic od siebie. Bo dyrektor nas zabije. Dyscyplina i porządek. Edukacja - Kopulacja. Nikt nie wierzy w to, co słyszy. Każdy głową potakuje. Bo na stopnie to rzutuje. Edukacja - Kopulacja. Kto podliże się roztropnie. Ten otrzyma lepsze stopnie. Tak do końca życia będzie. Edukacja - Kopulacja. Chcemy wiedzieć coś o życiu. Lecz profesor się z nas śmieje. Dranie, durnie i złodzieje. W szkole ustrój niewolniczy. W szkole bezmózgowca życie. Taką szkołę w nosie mamy! (Śmierć Kliniczna, 1983).

„Nasza edukacja” została nawet dostrzeżona przez oficjalną prasę. Liliana Andruszewska, ubolewając nad niskim poziomem językowym tekstów Śmierci Klinicznej, pisała z ironią na łamach "Trybuny Robotniczej":

Nic dodać nic ująć. Krytyka systemu szkolnego bezkompromisowa, odkrywcza i głęboka. Spokoju mi tylko nie dawała ta "kopulacja». Czyżby to aluzja do źle przeprowadzanych lekcji »przysposobienia do życia w rodzinie«? A może to się po prostu fajnie rymowało, co jak widać z tekstu ma dla autora niebagatelne znaczenie (...) Kończąc lekturę można jedynie westchnąć, by moda na tego rodzaju teksty (...) umarła śmiercią naturalną (Andruszewska, 1983, s. 5).

Życzenia dziennikarki się nie spełniły, choć po premierze piosenki w radiowej „Trójce” interweniował podobno, oburzony jej treścią, działacz Polskiej Zjednoczonej Partii Robotniczej. W efekcie „Nasza edukacja” dostała zakaz emisji radiowej (Dusza, 2016, s. 140).

Formalnie zespół przestał istnieć pod koniec 1984 roku. Dusza założył po rozpadzie „Śmierci” postpunkowy „Absurd”. Z kolei Jerzy Mercik, Jacek Szafir i Wojciech Jaczyczko powołali do życia zespół R.A.P.

R.A.P. powstał jesienią 1985 roku w Gliwicach. Oprócz wspomnianych muzyków Śmierci Klinicznej w zespole występowali także Marek Rogowski (jako trzeci wokalista obok Jerzego Mercika i Jacka Szafira), Ireneusz Zawadzki (gitara) oraz Dariusz Mazurkiewicz (perkusja). Nazwa zespołu jest połączeniem dwóch wyrażeń. Skrótu zdania „Reggae Against Politics" („Reggae Przeciwko Polityce”) i angielskiego czasownika "rap” ( "szturchnacć”, "skrytykować”, "stukać”). Z rapem jako gatunkiem muzycznym twórczość tej gliwickiej formacji nie mała nic wspólnego. R.A.P był zespołem reaggowym i to w pełnym tego słowa znaczeniu. Co więcej, zespołem w opinii krytyków muzycznych zdecydowanie wyróżniającym się na tle innych polskich zespołów grających reggae:

RAP był najlepszą polską grupą wykonującą czarną muzykę (...) potrafił doskonale pokazać nie tylko duchowy i rytmiczny wymiar reggae, ale też - chyba jako jedyny w Polsce - jego drapieżną stronę, ciemną i brudną sferę właściwą każdej muzyce korzennej. Był mistrzem w budowaniu zadziwiająco spójnych i przebojowych wielowątkowych kompozycji, które w ciągu kilku minut wypowiadały całą esencję reggae, jego korzeni i jego pochodnych (Księżyk, 1997). 
R.A.P. instytucjonalnie związany był z klubem Politechniki Śląskiej „Gwarek”. W piwnicy tego klubu odbywały się próby R.A.P, które pierwotnie były traktowane jako rodzaj rozgrzewki do prób Śmierci Klinicznej. Na początku działalności R.A.P. wykonywał utwory Boba Marley'a i brytyjskich zespołów Aswad i Steel Pulse. Później powstały pierwsze własne utwory R.A.P.: "I stand" (A Lonely Man) i "My Women", do których teksty napisał Jacek Szafir. Nie była to jednak - jak wspomina po latach Jerzy Mercik - „jakaś poważna twórczość” („R.A.P.: Graliśmy ostrzej, po swojemu”, 2017). Trudno się z tą opinią nie zgodzić. Piosenkom tym daleko - zarówno pod względem muzycznym, kompozycyjnym i tekstowym - do takich utworów R.A.P. jak "Generation" czy "Reggae Rockers".

R.A.P. zadebiutował 26 lutego 1986 roku w Gliwicach na Festiwalu Winter Reggae i prawie od razu zdobył uznanie publiczności i krytyków. Jeden z dziennikarzy miesięcznika "Non Stop" - jednego z najbardziej znanych polskich pism muzycznych lat 70. i 80. - pisał o koncercie R.A.P. z entuzjazmem:

Ten zespół to moja jedyna satysfakcja i świeżość na tym festiwalu. JAH spraw, żeby nie zaczęli kombinować, a doskonalili to, co z łaski Twojej na pewno posiadają, bo to słychać. Że śpiewają prawdziwie dało się słyszeć choćby po swojskich góralskich harmoniach pobrzmiewających momentami (cyt. za: R.A.P., Follow the Sun 1998).

Choć R.A.P. istniał na polskiej muzycznej scenie undergroundowej tylko dwa lata (1985-1987), wystąpił na najważniejszych polskich festiwalach muzycznych takich jak Reggae nad Wartą w Gorzowie Wielkopolskim, Rób Reggae w Warszawie, gdzie zagrał między innymi u boku legendy brytyjskiego reggae, zespołu Misty in Roots. Znamienny był również występ R.A.P. na Festiwalu Muzyków Rockowych w Jarocinie w 1986 roku, którego fragment został zarejestrowany w filmie dokumentalnym My Blood, Your Blood. W filmie R.A.P. wykonuje wspomniany już utwór "Generation". Ten swoisty reggae'owy protest song wydaje się dobrze oddawać nastroje części polskiej młodzieży lat 80., która nie potrafiła się odnaleźć w ówczesnym, represyjnym systemie politycznym: „We are generation R.A.P. We are generation dread. We are generation R.A.P. We are no red, we are no red!" (R.A.P., 1998).

Z kolei w chyba najsłynniejszym utworze, "Reggae Rockers”, będącym w warstwie muzycznej dynamiczną mieszanką reggae i ska, R.A.P. pokłada nadzieję na zmianę zastanej rzeczywistości w przyjściu JAH. Występujące w tekście słowo JAH jest skróconą wersją imienia Jahwe - starotestamentowego Boga. W powiązanej z muzyką reggae subkulturze rastafarian za religijny symbol dla boga wcielonego (JAH) uznawany był ostatni cesarz Etiopii Hajle Selasje I (Pęczak, 1992). Z tekstu "Reggae Rockers” wyłania się utopijny obraz świata wolnego od przemocy:

$|\&|$, I\&I I believe. That my Day oh my day's commin' to me. My sun is ready to shine, my rain to fall. My eyes for tears and face to smile (...) $|\&|,|\&|$ am sure that we'll be saying the truth. there'll be no guns and the blood on the streets (...) no police, no soldiers who're lookin for me. Fire burn, oh... fire. Love Jah, love Jah \& wait" (R.A.P., 1998).

Absurd był kolejnym zespołem GAS powstałym w 1984 roku na gruzach Śmierci Klinicznej. Oprócz gitarzysty Dariusza Duszy w skład Absurdu wchodzili: Jarosław Lumpe "Lumpaj" (śpiew), Lucjan Gryszka (gitara basowa)4 oraz Krzysztof Kamiński „Marlena” (perkusja). Pomimo że zespół działał tylko dwa lata, zdążył zdobyć uznanie jako jeden z najbardziej oryginalnych zespołów nowofalowo-punkowych lat 80. w Polsce. W latach

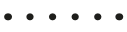

4 Przed Lucjanem Gryszką na gitarze basowej grał Adam Hagno (Dusza, 2015). 
1984-1986 zespół wystąpił na wielu znanych festiwalach muzycznych. Oprócz Festiwalu Muzyków Rockowych w Jarocinie, grał między innymi na Grand Festiwalu Róbrege w Warszawie oraz na Festiwalu Artystycznym Młodzieży Akademickiej (FAMA) w Świnoujściu (Dusza, 2015).

Marazm, brak perspektyw na lepsze jutro, bezsilność, szara beznadzieja, nieufność do ludzi, strach przez konfliktem nuklearnym (lata 80. to przecież czas "zimnej wojny”) te wszystkie odczucia, które towarzyszyły wielu młodym Polakom w latach 80., rezonują W wielu tekstach Absurdu. Między innymi w jednozwrotkowej piosence "Nasze realia to anomalia" (Absurd, 2018) i w utworze "Zżera mnie dżuma” znajdującym się na jedynym, wydanym w latach 80., singlu Absurdu:

Chciałbym zrobić nie wiadomo co. Chciałbym uciec nie wiadomo gdzie. Chciałbym zostać nie wiadomo kim. Lecz nie mogę, nie mam sit. Bez nadziei płynie dzień za dniem. Bez nadziei i bez żadnych tez. Świat gdzieś dalej toczy się. Gdzieś za ścianą życie wre (...) Chciałbym zrobić nie wiadomo co. Chciałbym uciec nie wiadomo gdzie. Chciałbym zostać nie wiadomo kim. Lecz nie mogę, nie mam sił. Gdzie nie spojrzę, wszystko drażni mnie. Gdzie nie będę, tam mi będzie źle. Żaden człowiek nie pomoże mi. Wszystkich przecież zżera dżuma dziś. Odejść, zapomnieć. Czy też wszystko pamiętać? Jak zwalczyć chorobę? Czy warto, czy warto? (...) Zżera mnie dżuma (Absurd, 1987, 2018).

A także w piosence "Wierszyk":

Piękna nasza ziemia cała. Dziś w powietrze wyleciała. Atomowych grzybów las. Wreszcie pozabijał nas. Optymiści, dekadenci, kurwy, starcy, prominenci. Politycy, księża, dzieci, uczeni i analfabeci. Żołnierze i emeryci, narkomani i bandyci. Pederaści, zoofile, wszyscy we wspólnej mogile. Za kilka milionów lat. Znów się narodzi świat. Małpa z drzewa zechce zejść By cywilizację wznieść. Znów powstaną piękne nowe. Schrony przeciwatomowe. Nowe czołgi i rakiety. Nowe więzienia i kacety. Nowe myśli, transparenty. Nowi święci, nowe męty. Nowe kłamstwa, prawdy nowe. Nowe, nowe, wszystko nowe. Lecz nie cieszcie się tym dzieci. Znów w powietrze świat wyleci (Absurd, 2018).

Kolejnym zespołem GAS, którego twórczość chcielibyśmy przybliżyć, jest Processs. Grupa powstała w październiku 1982 roku w Pyskowicach nieopodal Gliwic. A potrzeba założenia zespołu - jak wspomina Andrzej Mierzwa - zrodziła się z poczucia wściekłości na sytuację społeczno-polityczną w Polsce początku lat 80. W szczególności na wprowadzenie stanu wojennego, który położył kres „karnawałowi Solidarności” - trwającemu od sierpnia 1980 roku do 13 grudnia 1981 roku okresowi względnej liberalizacji systemu komunistycznego:

(...) Przez kilkanaście miesięcy żeśmy uwierzyli w (...) okres odwilży, wolności i swobody. Cieszyliśmy się tym. Nagle zostało to wszystko zdławione, stłamszone, zniweczone. W zasadzie nie zostało nic. Jedynie w człowieku rodził się jakiś bunt, wściekłość. Potrzeba wyrażenia tego wszystkiego, opisania. I trzeba było znaleźć jakieś środki wyrazu. Akurat w naszym przypadku była to muzyka i punk rock i postanowiliśmy założyć zespót i tak zaczęliśmy tę naszą formację składać. Tworzyć teksty, pisać teksty, pisać muzykę („Wywiad z Andrzejem Mierzwą dla Programu 1 Polskiego Radia", 2013).

W latach 1983-1984 Processs występował w składzie: Andrzej Mierzwa (śpiew), Piotr Żukowski "Siwy” (gitara basowa), Ryszard Wójcik „Kigen” (perkusja), Arek Jurek "Nawiedzony" (instrumenty perkusyjne) oraz Bogdan Witas „Bogi” (gitara). W 1985 roku zadebiutował na Festiwalu Muzyków Rockowych w Jarocinie. W tym samym roku zarejestrował w studiu CCS piosenkę "Kolejny krok cywilizacji”, która trzy lata później ukazała się na albumie kompilacyjnym „Radio nieprzemakalnych". 
We wspomnianym utworze, przyjmującym formę swoistej punkowej antyutopii, kreślona jest wizja na wskroś bezdusznego i zautomatyzowanego świata:

Pozamykajmy wszystkie okna. Okna! By nie oddychać świeżym powietrzem. Powietrzem! Porozbijajmy wszystkie lustra. Lustra! By nie oglądać swoich twarzy. Twarzy! Porozbijajmy wszystkie zegary. Zegary! By nie odmierzać swego czasu. Czasu! Niedługo będzie operacja. Operacja! Plastyczna operacja twarzy. Twarzy! Bez twarzy, bez serca, bez duszy, automat! Potem ubiorą w garnitury. Garnitury! Szare do ślubu i do pracy. Do pracy! Będziemy słuchać (...) muzyki. Muzyki! Wypływającej z kilku maszyn. Maszyn! I zjednoczymy się w jedno ciało. Ciało! Komputerowe doskonałe (Radio nieprzemakalnych, 1988)

W 1986 roku Processs ponownie zagrał na festiwalu jarocińskim, a występ zespołu został uwieczniony w przywołanym już filmie My Blood, Your Blood. W dokumencie zespół wykonuje chyba swój najsłynniejszy utwór "Stroszek". Piosenka ta nawiązuje - zarówno w tytule jak i treści - do stynnego filmu Wernera Herzoga. Jak wspomina Andrzej Mierzwa, jej powstanie zbiegło się z okresem, kiedy w polskiej telewizji pokazywano filmy tego wybitnego niemieckiego reżysera:

Cały cykl [filmów - przyp. aut.] w środku nocy był puszczany (...) te filmy tak przypadły mi do gustu (...), że spałem w dzień, a w nocy nastawiałem budzik i oglądałem, żeby zobaczyć do końca. No i jednym właśnie z filmów był "Stroszek«, który treścią (....) był bliski tekstowi, który powstał wcześniej, łącznie z puentą (...) I stąd to skojarzenie tak mi spasowało, że [nasz utwór tak - przyp. aut.] nazwałem i zostało do dzisiaj („Wywiad z Andrzejem Mierzwą dla Programu 1 Polskiego Radia", 2013).

Z tekstu piosenki wyłania się obraz człowieka osaczonego przez represyjny system (w filmie Herzoga to system kapitalistyczny), akceptujący tylko zachowania zgodne z przyjętymi, obowiązującymi normami. Wszelkie przejawy niezależnego myślenia redukowane są do choroby psychicznej. W niezwykle motorycznym i zarazem psychodelicznym, postpunkowo-nowofalowym utworze, którego możemy posłuchać między innymi na albumie kompilacyjnym „Jak punk to punk" (1986), zespół Processs śpiewa:

Zwariowane koło, wszystkich opętało. Nawet nie wiesz co myślisz. Co się z tobą stało. Nigdzie nie uciekniesz, rozszarp swoje ciało. A nie zwrócą uwagi, co się z tobą stało. Co się z tobą stało. Mieścisz się w normie i machasz rękami. Łapiesz powietrze, cudzymi ustami. Za chwile patrzysz, patrzysz nie widzisz. Wszystko zalane. Zalane, zalane. Standard analiza, standardowa diagnoza. I wariat, wariat, wariat! (Jak punk to punk, 1986).

Historia tej piosenki na filmie My Blood, Your Blood się nie kończy. Bodajże w 1987 roku, za namową Jerzego Fedaka, do utworu "Stroszek" został nakręcony - prawdopodobnie pierwszy w historii Polskiej Telewizji - undergroundowy teledysk (Ruczko, 2016). Utwór Processsu zyskał głębię przekazu. Fedakowi et consortes udało się doskonale zsynchronizować dekadencki charakter piosenki z przygnębiającym obrazem szarych śląskich ulic końca dekady. Pikanterii dodaje fakt, że sponsorem teledysku był Zakład Mechaniczny Bumar-Łabędy słynący z produkcji czołgów dla polskiej armii („Wywiad z Andrzejem Mierzwą dla Programu 1 Polskiego Radia", 2013). Dodajmy, że Processs reaktywował się w 2013 roku i jest jedynym zespołem GAS działającym do dziś.

Ostatnim zespołem GAS, którego twórczość chcielibyśmy przybliżyć, jest Brzytwa Ojca. Początki działalności tego gliwickiego ansamblu sięgają 1984 roku. Około 1986 roku ustabilizował się skład zespołu, który przetrwał prawie do końca jego działalności, czyli do 1989 roku. Brzytwę Ojca tworzyli wówczas: Pastor (śpiew), Dariusz Borówka (gitara), Dariusz Jochimczyk (gitara basowa) oraz Kissman (perkusja). Podobnie jak Śmierć Klinicz- 
na, Absurd i R.A.P., zespół był związany z gliwickim klubem "Gwarek". W latach swojej działalności Brzytwa Ojca licznie koncertowała, grając między innymi w 1987 i 1988 roku na Festiwalu Muzyków Rockowych w Jarocinie. W 1988 roku zespół nagrał demo „Underground", którego muzyczny klimat chyba najlepiej oddaje krótki opis znaleziony przez nas na stronie internetowej wydawnictwa Zima: „Brzytwa Ojca to śląski ansambl grający ostrego załoganckiego punk rocka, w 'jarocińskim' stylu (...) z mocno nihilistycznym i destrukcyjnym przesłaniem” („Brzytwa Ojca! Brzytwa ojca!”, b.d.). Faktycznie, obraz świata społecznego wyłaniający się z tekstów piosenek Brzytwy Ojca - tak jak zdecydowana większość analizowanych tutaj piosenek zespołów tworzących GAS - nie nastraja optymistycznie. Rzeczywistość schyłku PRL charakteryzowana jest jako przestrzeń, w której dominuje chaos, międzyludzka nienawiść i bezsensowna walka o władzę:

Nowa armia patriotów objęła władzę swą. Bez sensu i celu ciągła walka o tron. Przed gilotyną już zebrany ludzi tłum. Będą ścinać według zasług według ulg (...) Kiedy ręce kajdanami zniewolone masz. Padając na kolana w ziemię wbijasz swoją twarz. Totalna nienawiść opętała was. Zaciskasz swoje więzy terroryzując nas. Destrukcja i chaos anarchia nienawiść (Brzytwa Ojca, 2012)

Nota bene, nie tylko peerelowska szara rzeczywistość jest poddawana krytyce. W piosence "Ameryka" "Brzytwa Ojca" demaskuje fasadowość systemu demokratycznego w Stanach Zjednoczonych. Jest to nieco zaskakujące, biorąc pod uwagę fakt, że w czasach PRL, Ameryka przez gros Polaków była postrzegana niczym biblijna ziemia obiecana. Z tekstu piosenki wyłania się obraz kraju, w którym pod przykrywką wzniosłych idei dominuje kult pieniądza i rozwarstwienie społeczne:

Gdzieś na mapie świata jest taki piękny kraj. Gdzie ludziom nic nie trzeba, bo każdy wszystko ma. Tam zasad demokracji przestrzega każdy pan. Panowie ci są wielcy, bo wielki jest ten kraj

(...) Gdzieś na mapie świata jest taki piękny kraj. Gdzie może robić wszystko, kto pieniądze ma.Tam zasad demokracji przestrzega każdy pan. A biedni śpią w kartonach, bo to jest wolny kraj (...) Kolorowe ulice i domy kuszą swym widokiem. Martwe witryny wystaw, one kłamią, one kłamią. Ameryka, Ameryka. Niszcz USA! (Brzytwa Ojca, 2012).

Świat w tekstach zespołu jest także światem całkowicie wyzutym z ludzkich uczuć, gdzie nie ma miejsca na miłość i realizację pragnień: „Wszędzie kłamstwo i obłuda. Zaciemniony brudem świat. Niespełnione nasze sny. Nasze skryte pragnienia. Żegnaj miłości. Ludzkie uczucie. Nie ma miłości. Ludzkich uczuć" (Brzytwa Ojca, 2012).

Przywołane przez nas teksty piosenek nie wyczerpują bogatego dorobku zespołów tworzących GAS. Idąc za wskazówką Michaela Pattona, przeanalizowaliśmy tylko kilkanaście utworów, starając się dobierać do analizy te najbardziej zróżnicowane pod względem semantycznym i muzycznym. Chcieliśmy w ten sposób jak najlepiej uchwycić zmienność i różnorodność interesującego nas pola badawczego (Patton, 2002, cyt za: Flick, 2010, s. 59). Nie ulega jednak wątpliwości, że Gliwicka Alternatywna Scena zasługuje na opracowanie wykraczające poza ramy tego artykułu.

\section{PODSUMOWANIE}

Fenomen Gliwickiej Alternatywnej Sceny sam w sobie jest dobrą ilustracją szerszego zjawiska, jakim była subkulturowa, wykorzystująca "szare strefy" kultury niekontrolowanej do końca przez władze, część polskiego boomu rockowego. W zestawieniu z innymi re- 
prezentantami tego nurtu - z Warszawy, Trójmiasta, Krakowa i innych miast - zespoły współtworzące GAS wyróżniały się radykalizmem tekstów piosenek. Klimaty beznadziei, osaczenia, opresji wydają się tu mocniej podkreślane niż w powstałych w tym samym czasie piosenkach sceny gdańskiej, warszawskiej, czy rzeszowskiej. Nic dziwnego, że stały się później wzorcem dla schyłkowej fali rodzimego punka z końca lat 80. i początku 90. Być może ten radykalizm wynikał z zapatrzenia w brytyjskie zespoły punkrockowe, o czym wspomnieliśmy wcześniej, a po części też z apatii, jaką wywołał stan wojenny i trwający nieprzerwanie od 1976 r. kryzys ekonomiczny. Można jednak uznać, że jest to cecha konstytutywna śląskiego punka, który - podobnie jak śląski blues czy śląski metal - zaabsorbowat, świadomie lub w toku procesu "osmozy kulturowej”, charakterystyczną dla regionu atmosferę fatalizmu, a poniekąd też podwójnego wykluczenia: klasowego i kulturowego (Śląsk robotniczy i nie dość „polski”). Tak czy inaczej, gdy patrzymy na Gliwicką Alternatywną Scenę po latach, nie ma wątpliwości, że była ona czymś bardzo ważnym dla rockowej publiczności i pozostaje do dziś czymś bardzo ciekawym dla badaczy rodzimej kultury alternatywnej.

\section{BIBLIOGRAFIA}

Andruszewska, L. (1983, październik 7). Agonia dobrego smaku: Piosenki „Śmierci Klinicznej". Trybuna Robotnicza, s. 5.

Bornat, J. (2004). Oral history. W C. Seale i in. (Red.), Qualitative research practice (ss. 34-47). London: Sage.

Brzytwa Ojca! Brzytwa ojca! (b.d.). Pobrano 22 kwietnia 2018, z https://sklep.zima.slask. pl/857-brzytwa-ojca-brzytwa-ojca.html

Chosiński, S. (2012, wrzesień 25). Underground from Poland: "Świat jest jednym wielkim obozem koncentracyjnym" - prawda czy fałsz? Pobrano 22 kwietnia 2018, z http:// esensja.stopklatka.pl/muzyka/recenzje/tekst.html?id=14973\&strona=1\#strony

Discogs: Database and marketplace for music on vinyl, CD, cassette and more. (b.d.). Pobrano z www.discogs.com

Dusza, D. (2015). Wywiad narracyjny.

Dusza, D. (2016). Jestem ziarnkiem piasku. Pyskowice: Wyd. ZIMA Firma FonograficznoHandlowa.

Flick, U. (2010). Projektowanie badania jakościowego. Warszawa: Wydawnictwo Naukowe PWN.

Grabowski, K. (2010). Poroniona generacja. Warszawa: Wyd. Agora.

Hoggart, R. (1976). Spojrzenie na kulture robotniczą w Anglii. Warszawa: Państwowy Instytut Wydawniczy.

Księżyk, R. (1997). Recenzja płyty „RAP Generation”. Brum, (b.n.).

Kvale, S. (2010). Prowadzenie wywiadów. Warszawa: Wydawnictwo Naukowe PWN.

Lesiakowski, K., Perzyna, P., \& Toborek, T. (2004). Jarocin w obiektywie bezpieki. Warszawa: Instytut Pamięci Narodowej. Komisja Ścigania Zbrodni przeciwko Narodowi Polskiemu.

Lizut, M. (2003). Punk rock later. Warszawa: Wyd. Sic!

Marciniak, M. (2015). Transnational punk communities in Poland. From nihilism to nothing outside punk. Lanham: Lexington Books. 
Patton, M. Q. (2002). Qualitative evaluation and research methods. London: Sage.

Pęczak, M. (1992). Mały słownik subkultur młodzieżowych. Warszawa: Wyd. Semper.

Pęczak, M. (2013). Subkultury w PRL: Opór, kreacja, imitacja. Warszawa: Narodowe Centrum Kultury.

R.A.P., Follow the Sun [Wkładka płyty CD]. (1998). Pyskowice: Wyd. ZIMA Firma Fonograficzno-Handlowa.

R.A.P.: Graliśmy ostrzej, po swojemu [Rozmowa z Jerzym Mercikiem i Jackiem Szafirem]. (2017). Pobrano 21 marca 2018, z https://www.freecolours.pl/r-a-p-gralismyostrzej-po-swojemu/

Ruczko, P. (2016). Processs - Wszystko dla jutra (2014) [Recenzja]. Pobrano 2 kwietnia 2018, z http://www.riversedge.pl/processs-wszystko-dla-jutra-2014-recenzja

SS 20 [Dezerter]. (b.d.). Nie płacz Zbyszek. Pobrano 13 marca 2018, z https://www.youtube.com/watch?v=s2z4Ob_7tiA

Szwed, E. (2010). Orkiestra dęta w tradycji muzycznej Śląska - historia, współczesność. Prace Naukowe Akademii im. Jana Długosza w Częstochowie: Edukacja Muzyczna, 2010(5), 91-97.

Śmierć Kliniczna 1982-1984 [Wkładka płyty CD]. (2001). Pyskowice: Wyd. ZIMA Firma Fonograficzno-Handlowa.

Wertenstein-Żuławski, J. (1993). Między nadzieją a rozpaczą. Warszawa: Instytut Kultury. Wertenstein-Żuławski, J., \& Pęczak, M. (Red.). (1991). Spontaniczna kultura młodzieżowa: Wybrane zjawiska. Wrocław: Wydawnictwo Wiedza o Kulturze.

Winnicka, E. (2000). Scenariusz dla moich sąsiadów. Polityka, 2000(8), 100-105.

Wywiad z Andrzejem Mierzwą dla Programu 1 Polskiego Radia. (2013). W Wschodni Front. Pobrano z youtube.pl

Płytoteka:

Absurd. (2018). Anomalia [LP]. Pyskowice: Zima Records.

Brzytwa Ojca. (2012). Brzytwa Ojca [CD]. Dębica: Pasażer.

Jak punk to punk: Album kompilacyjny [LP]. (1986). Warszawa: Tonpress.

Processs. (2014). Wszystko dla jutra [CD]. Pyskowice: Zima Records.

R.A.P. (1998). Follow the Sun [CD]. Pyskowice: Zima Records.

Radio nieprzemakalnych: Album kompilacyjny [LP]. (1988). Warszawa: Wifon.

Śmierć Kliniczna. (1983). Nienormalny świat [SP]. Warszawa: Tonpress.

Śmierć Kliniczna. (1984). Jestem ziarnkiem piasku [SP]. Warszawa: Tonpress.

Śmierć Kliniczna. (2001). Śmierć Kliniczna 1982-1984 [CD]. Pyskowice: Zima Records. 